\title{
Article
}

\section{Seismic Hazard Assessment for a Wind Farm Offshore England}

\author{
Brian Carlton ${ }^{1, *}$, Andy Barwise ${ }^{2}$ and Amir M. Kaynia ${ }^{3}$
}

1 Norwegian Geotechnical Institute, 0806 Oslo, Norway

2 RWE Renewables, Swindon SN5 6PB, UK; andy.barwise@rwe.com

3 Department of Structural Engineering, Faculty of Engineering, Norwegian University of Science and Technology, 7034 Trondheim, Norway; Amir.M.Kaynia@ngi.no

* Correspondence: brian.carlton@ngi.no

check for updates

Citation: Carlton, B.; Barwise, A.;

Kaynia, A.M. Seismic Hazard Assessment for a Wind Farm

Offshore England. Geotechnics 2022, 2, 14-31. https://doi.org/10.3390/ geotechnics2010002

Academic Editors: George Mylonakis and Yumin Chen

Received: 12 August 2021

Accepted: 3 November 2021

Published: 6 January 2022

Publisher's Note: MDPI stays neutral with regard to jurisdictional claims in published maps and institutional affiliations.

Copyright: (C) 2022 by the authors. Licensee MDPI, Basel, Switzerland. This article is an open access article distributed under the terms and conditions of the Creative Commons Attribution (CC BY) license (https:// creativecommons.org/licenses/by/ $4.0 /)$.

\begin{abstract}
Offshore wind has become a major contributor to reducing global carbon emissions. This paper presents a probabilistic seismic hazard analysis for the Sofia Offshore Wind Farm, which is located about $200 \mathrm{~km}$ north-east of England in the southern North Sea and will be one of the largest offshore wind farms in the world once completed. The seismic source characterization is composed of two areal seismic source models and four seismic source models derived using smoothed gridded seismicity with earthquake catalogue data processed by different techniques. The ground motion characterization contains eight ground motion models selected based on comparisons with regional data. The main findings are (1) the variation in seismic hazard across the site is negligible; (2) the main source controlling the hazard is the source that includes the 1931 Dogger Bank earthquake; (3) earthquake scenarios controlling the hazard are $M_{w}=5.0-6.3$ and $R=110-210 \mathrm{~km}$; and (4) the peak ground accelerations on rock are lower than for previous regional studies. These results could help guide future seismic hazard assessments in the North Sea.
\end{abstract}

Keywords: probabilistic seismic hazard analysis; stable continental region; North Sea; Dogger Bank

\section{Introduction}

The Sofia Offshore Wind Farm is located about $200 \mathrm{~km}$ north-east of England in the southern North Sea (Figure 1). It is on an isolated bank of sediment that forms a bathymetric high called Dogger Bank, in water depths ranging from 20 to $35 \mathrm{~m}$. When completed, it will contain 100 wind turbines, spread over an area of $593 \mathrm{~km}^{2}$, with an installed capacity of $1400 \mathrm{MW}$, making it one of the largest and furthest-from-land offshore wind farms in the world.

Even small amounts of permanent tilt caused by earthquake shaking or liquefaction could affect wind turbine performance [1]. Therefore, it is important to have a reliable estimate of the seismic hazard. One of the first seismic hazard assessments covering the project location was conducted by Principia Mechanica Ltd. in 1986 [2]. Other significant early seismic hazard studies including the project location are the reports by BGS \& Ove Arup and Partners in 1997 [3], and the joint UK-Norwegian study by EQE International Ltd. and NORSAR in 2000 [4-6]. These early studies were mainly motivated by the growing offshore oil and gas industry in the North Sea. However, a review study in 2003 [7] pointed out significant shortcomings with these reports such as a lack of transparency and detail in the methodology, limitations in the ground motion models used, and the fact that they only provide peak ground acceleration (PGA) values. In 2004, the International Organization for Standardization (ISO) introduced standard 19901-2, which governs the seismic performance of offshore oil and gas structures. ISO 19901-2 was updated in 2017 [8] but the hazard values for the North Sea remained the same. As a result, the available seismic hazard estimates for the project location are almost 20 years old and focused mainly on offshore oil and gas structures. Therefore, to provide a reliable basis for seismic design, a site specific probabilistic seismic hazard analysis (PSHA) for representative bedrock site conditions for 
the corners and center of the Sofia Offshore Wind Farm was performed. The results of the study will help ensure adequate performance of the wind turbines at the Sofia Offshore Wind Farm in the event of an earthquake and will also provide insight into the seismic hazard of the North Sea that could improve future seismic hazard assessments.

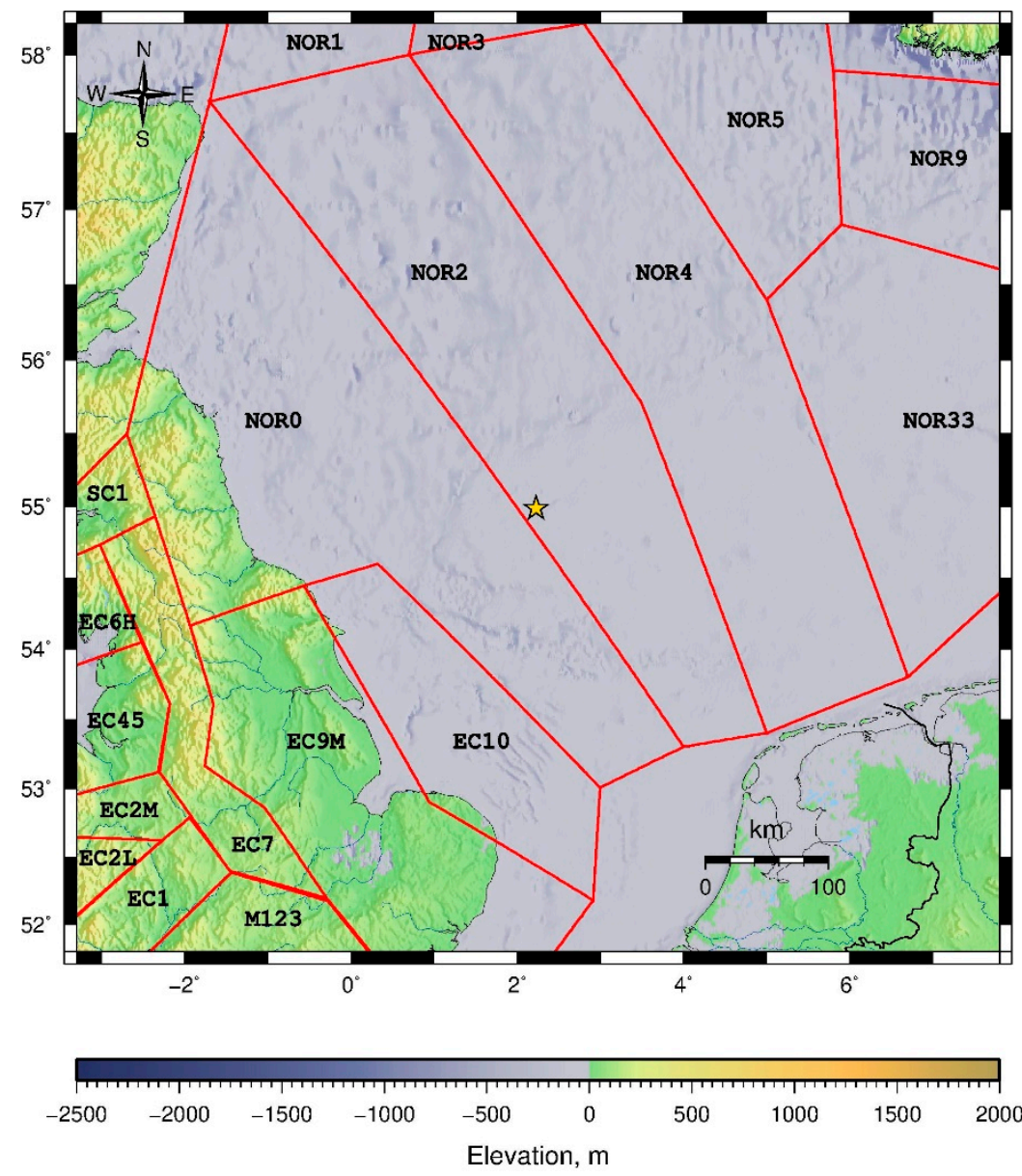

Figure 1. Location of areal source zones for SSM1 based on Bungum et al. 2000 and Musson and Sergeant, et al. 2007. The yellow star indicates the center of the wind farm zone.

Section 2 outlines the basic components of PSHA and Section 3 provides an overview of the geologic and tectonic setting of the study area. Section 4 describes the source characterization based on recorded and historical earthquake events as well as seismic source models from available relevant past studies, and Section 5 summarizes the ground motion models used in the PSHA. Finally, Section 6 presents the results of the PSHA and Section 7 summarizes the main findings and implications for other seismic hazard analyses in the North Sea.

\section{Overview of PSHA Methodology}

PSHA is a methodology that estimates the probability that an earthquake intensity measure will be exceeded at a given location in a set future time period. The main purpose of a PSHA is to aid in the decision of what level of an intensity measure to use in the design of a structure to ensure a desired performance state, and what magnitude and distance combination is most likely to produce the chosen level of the intensity measure [9].

The PSHA calculations described in this paper were performed using a modified version of the HAZ45.2 computer program developed by Norman Abrahamson [10,11]. This program implements the PSHA methodology, which was developed principally by Cornell [12] and refined by McGuire [13,14]. This PSHA methodology has five basic components, which are listed below. 
1. Identify all relevant earthquake sources.

2. Characterize the rates at which earthquakes of various magnitudes $(M)$ are expected to occur for each source.

3. Characterize the distribution of source-to-site distances $(R)$ for each source.

4. Predict the chosen intensity measure for all combinations of magnitude, distance and $\varepsilon$ (the number of standard deviations of the ground motion model used to estimate the intensity measure) for each source.

5. Combine the probabilities of $M$ and $R$ to calculate the rate of each $M$ and $R$ scenario. Then, for each $M$ and $R$ scenario, use a ground motion model to calculate the probability of the desired intensity measure (usually spectral acceleration for a given structural natural period) being greater than a threshold value. Multiply the rate of the $M$ and $R$ scenario by the probability of the intensity measure and sum over all scenarios. Repeat step 5 for different threshold values to calculate the hazard curve.

In PSHA, many of the input parameters have uncertainty due to limited data or knowledge. This uncertainty, called epistemic uncertainty, is incorporated into the PSHA using a logic-tree framework [15]. Each branch of the logic tree represents an alternative credible model or parameter value and is given a weight. The weights at each branch tip are mutually exclusive and collectively exhaustive, and they must sum to one. The weights are based on expert judgment of how accurate or 'credible' each alternative model is. In this way, the use of a logic tree allows multiple credible models to be included in the PSHA. When using a logic tree, a separate PSHA is conducted for each combination of alterative models (i.e., each final branch of the logic tree). Then, all the different hazard curves are combined using the branch weights to estimate the mean hazard.

\section{Tectonic Background}

\subsection{Geologic Setting}

Today, the North Sea is an extended stable continental region far from any tectonic plate boundaries [16]. The closest boundaries are the Mid Atlantic Ridge over $1500 \mathrm{~km}$ to the north and west, and the boundary between the Eurasian and African plates almost $700 \mathrm{~km}$ to the south. The overall stress pattern of the North Sea is NW-SE and mainly due to ridge push forces from the Mid-Atlantic Ridge and the collision of Africa and Europe [17].

Even though the levels of seismic hazard on a global scale are relatively low [18], the tectonic development of the region is complex. Volcanic activity during the Triassic and Jurassic (roughly 250-150 million years ago) created a system of horsts and grabens, which are highs and lows separated by normal faults. This was followed by thermal subsidence, which created an intracratonic sedimentary basin [19]. In the Paleocene/Eocene (65.5-34 million years ago), sea floor spreading began in the north Atlantic and mountain building began in the Alps, and basin margins in the North Sea were uplifted due to inversion, producing a series of submarine fans [20]. Over the last 2.5 million years, large volumes of sediment were eroded from Scandinavia and the UK and deposited in the North Sea by the movement of ice sheets during at least three different glacial periods. As the ice moved forwards and backwards, thrust moraines formed that were then subsequently overridden and eroded [21]. The changes in climate also resulted in regional-scale oscillations in sea level and major changes in river drainage configurations [22]. The complicated interactions between ice sheets and sea level change formed Dogger Bank, which emerged as an isolated bathymetric high with sediments up to $800 \mathrm{~m}$ thick [21]. Dogger Bank was submerged between 8000-5500 years ago due to rising sea levels following the last glacial period.

\subsection{Seismicity of the UK}

Musson and Sargeant [23] defined three broad crustal blocks that make up the UK and Ireland: the Laurentian crust in the north, Avalonian crust in the south and the Iapetus Suture Zone separating the former two. The Iapetus Suture Zone formed 460-420 million 
years ago when Laurentia and Avalonia fused, closing the Iapetus Ocean. The Sofia Offshore Wind Farm sits on the Avalonian crust just to the south of the Iapetus Suture Zone.

Chadwick et al. [24] developed a seismotectonic model for the UK based on projections of subsurface geological structures. It was the first model based more on geologic interpretation rather than the distribution of recorded earthquakes. They found a poor correlation between earthquake occurrence and individual bulk crustal properties such as crustal thickness or heat flow, but moderate correlation with tectonic features such as shear zones. Based on in-situ stress measurements from boreholes and earthquake focal mechanisms, they found that the maximum horizontal stress in the crust is oriented northwest-southeast, which they attribute to ridge-push from the Mid Atlantic Ridge divergent boundary. However, this stress is weak, and unable to reactivate either deep crustal thrust faulting or shallower basin normal faulting. This supposition is reinforced by the fact that earthquake focal mechanisms in the UK are predominantly strike-slip $[25,26]$, and there has been negligible deformation during the past 10 million years in sedimentary cover rocks. As a result, Chadwick et al. [24] hypothesized that most earthquakes are caused by minor interactions and adjustments between upper crustal blocks instead of by systematic and consistent relative block displacements. They believe that the shear zones form major areas of weakness in the crust and facilitate distributed strike slip faulting on transcurrent faults. However, using statistical tests, Musson [27] found that there is no correlation between the configuration of tectonic terranes and seismicity in the UK, but that the distribution of seismicity is non-random.

Another theory to explain the distribution of seismicity in the UK is post-glacial rebound. Musson [28] saw a correlation between earthquakes in Scotland and ice cover during the last glacial period. Extending this idea further, Muir Wood [29] suggested a model for earthquake distribution based on stress interference between radial stress fields due to post-glacial rebound and forebulge collapse, and general horizontal tectonic stress. However, Musson and Sargeant [23] stated that this theory does not adequately describe the observed seismicity either.

\section{Seismic Source Characterization}

The seismic source characterization defines the earthquake sources, their geometry, and the rate that earthquakes of various magnitudes are expected to occur on each source (magnitude recurrence relation). The first seismic source model (SSM1) is based on areal source zones from Bungum et al. [6] with additions from Musson and Sergeant [23] for locations near the UK, and the second seismic source model (SSM2) is based on the areal source model of the SHARE project [16]. In addition, four seismic source models, using smoothed gridded seismicity, were developed using an earthquake catalogue merged from the International Seismological Centre on-line bulletin [30] and the British Geological Survey [31]. All six seismic source models were then combined in a logic tree framework, with weights of 0.2 to SSM1, 0.4 to SSM2, and 0.1 to each of the four models developed using smoothed gridded seismicity.

\subsection{Magnitude Recurrence Relation}

A magnitude recurrence relation describes the rate at which earthquakes with magnitudes greater than or equal to $M$ occur on a source $N(M)$. The recurrence relation is calculated by integrating the magnitude probability density function $\left(f_{m}\right)$ from $M$ to the maximum magnitude considered $\left(M_{\max }\right)$ and multiplying by the activity rate $\left(N_{\min }\right)$ :

$$
N(M)=N_{\min } * \int_{m=M}^{M_{\max }} f_{m}(m) d m
$$

where the activity rate is the rate of earthquakes above a minimum magnitude $\left(M_{\min }\right)$ and the magnitude probability density function describes the relative number of earthquakes of various magnitudes that are expected to occur. All sources in this study used a truncated exponential model, which is a modified version of the Gutenburg and Richter model [32], 
and a minimum moment magnitude of $M_{\min }=4.0$. The minimum magnitude was set at 4.0 because this is likely the minimum magnitude to cause damage to infrastructure [33]. In addition to the minimum magnitude, maximum magnitude, and the activity rate, the truncated exponential model also requires a b-value. The b-value is the slope of the rate of earthquakes in log space and represents the ratio between large and small magnitude earthquakes for a source.

\subsection{Seismic Source Model 1}

Bungum et al. (2000) [6] was the first regional seismic hazard study for the entire North Sea and was a joint effort by Norwegian and UK researchers. Bungum et al. [5] described the model for Norway and the Norwegian sector of the North Sea, and the report by EQE [4] describes the model for the UK and the UK sector of the North Sea. Bungum et al. [5] used a coarse seismic source model consisting of 24 areal source zones and a fine seismic source model consisting of 37 areal source zones. The coarse model is the same as that used for Norway in the GSHAP project [18]. All source zones used a truncated exponential model with three sets of activity rate and b-value pairs implemented with different weights in a logic tree. EQE [4] extended both seismic source models to the UK and defined 38 areal source zones for the fine model and 26 for the coarse model. However, the values, weights and distributions of the activity rates of the different seismic source zones of the model used by EQE [4] are not publicly available.

As a result, this study used the areal source zones of Musson and Sergeant [23], who developed a seismic source model for the UK that includes some zones in the southern part of the North Sea. Their model was developed from the model of Chadwick et al. [24], discussed in Section 3.2, which is based mainly on tectonics and kinematics. Musson and Sergeant [23] modelled 20 different activity rate and b-value pairs for each areal source zone.

Seismic source model 1 (SSM1) is a combination of the fine models of Musson and Sergeant [23] and Bungum et al. [5]. Only the mean activity rate and b-values for each zone are used instead of the entire logic tree of different weighted values. Figure 1 shows the geometry and location of each of the areal source zones and Table 1 lists their activity rates $(\mathrm{N})$ and b-values. Zones that begin with NOR are from Bungum et al. [5] and the rest are from Musson and Sergeant [23], except NOR0. Areal source zone NOR0 was added to fill the gap between the two studies, using similar values as for Zone NOR2. This is a conservative assumption because the Musson and Sergeant [23] model has no seismic source for this area. Table 2 lists the maximum magnitudes used, which are the same as in Musson and Sergeant [23] and Bungum et al. [5].

Table 1. Source characteristics for SSM1.

\begin{tabular}{cccccc}
\hline Zone & $\boldsymbol{N}\left(\boldsymbol{M}_{\boldsymbol{m i n}}=\mathbf{4}\right)$ & $\mathbf{b}$-Value & Zone & $\boldsymbol{N}\left(\boldsymbol{M}_{\boldsymbol{m i n}}=\mathbf{4}\right)$ & b-Value \\
\hline SC1 & 0.0010 & 1.028 & EC6H & 0.0020 & 0.972 \\
EC7 & 0.0240 & 0.906 & NOR0 & 0.0012 & 1.050 \\
EC9M & 0.0070 & 1.005 & NOR1 & 0.0062 & 1.050 \\
EC10 & 0.0140 & 1.012 & NOR2 & 0.0012 & 1.050 \\
M123 & 0.0010 & 1.007 & NOR3 & 0.0451 & 1.050 \\
EC1 & 0.0140 & 0.926 & NOR4 & 0.0094 & 1.050 \\
EC2L & 0.0020 & 1.053 & NOR5 & 0.0103 & 1.050 \\
EC2M & 0.0030 & 1.062 & NOR9 & 0.0652 & 1.050 \\
EC45 & 0.0080 & 1.013 & NOR33 & 0.0022 & 1.050 \\
\hline
\end{tabular}

Table 2. Maximum magnitude model for SSM1.

\begin{tabular}{cccc}
\hline & $\boldsymbol{M}_{\max , \mathbf{1}}$ (Weight) & $\boldsymbol{M}_{\max , \mathbf{2}}$ (Weight) & $\boldsymbol{M}_{\max , \mathbf{3}}$ (Weight) \\
\hline UK onshore & $5.5(0.2)$ & $6.0(0.5)$ & $6.5(0.3)$ \\
UK offshore & $6.0(0.6)$ & $6.5(0.4)$ & - \\
Norway offshore & $6.0(0.4)$ & $6.5(0.4)$ & $7.0(0.2)$ \\
\hline
\end{tabular}




\subsection{Seismic Source Model 2}

The SHARE project [16] conducted a seismic hazard analysis for all of Europe. They used three different seismic source models; an areal source model, a fault source model with background seismicity, and an area-smoothed model based on fault slip rate and past seismic activity.

To define the second seismic source model (SSM2), a subset of the SHARE areal source model that included all areal sources within $350 \mathrm{~km}$ of the project location was used (Figure 2). Table 3 lists the parameters used in SMM2 [34]. The SHARE areal source model also includes weights for different faulting mechanisms ( $S S=$ strike slip, $\mathrm{N}=$ normal, $\mathrm{R}=$ reverse) and the top $\left(D_{\min }\right)$ and bottom $\left(D_{\max }\right)$ depths where earthquakes can occur in the areal source zone.

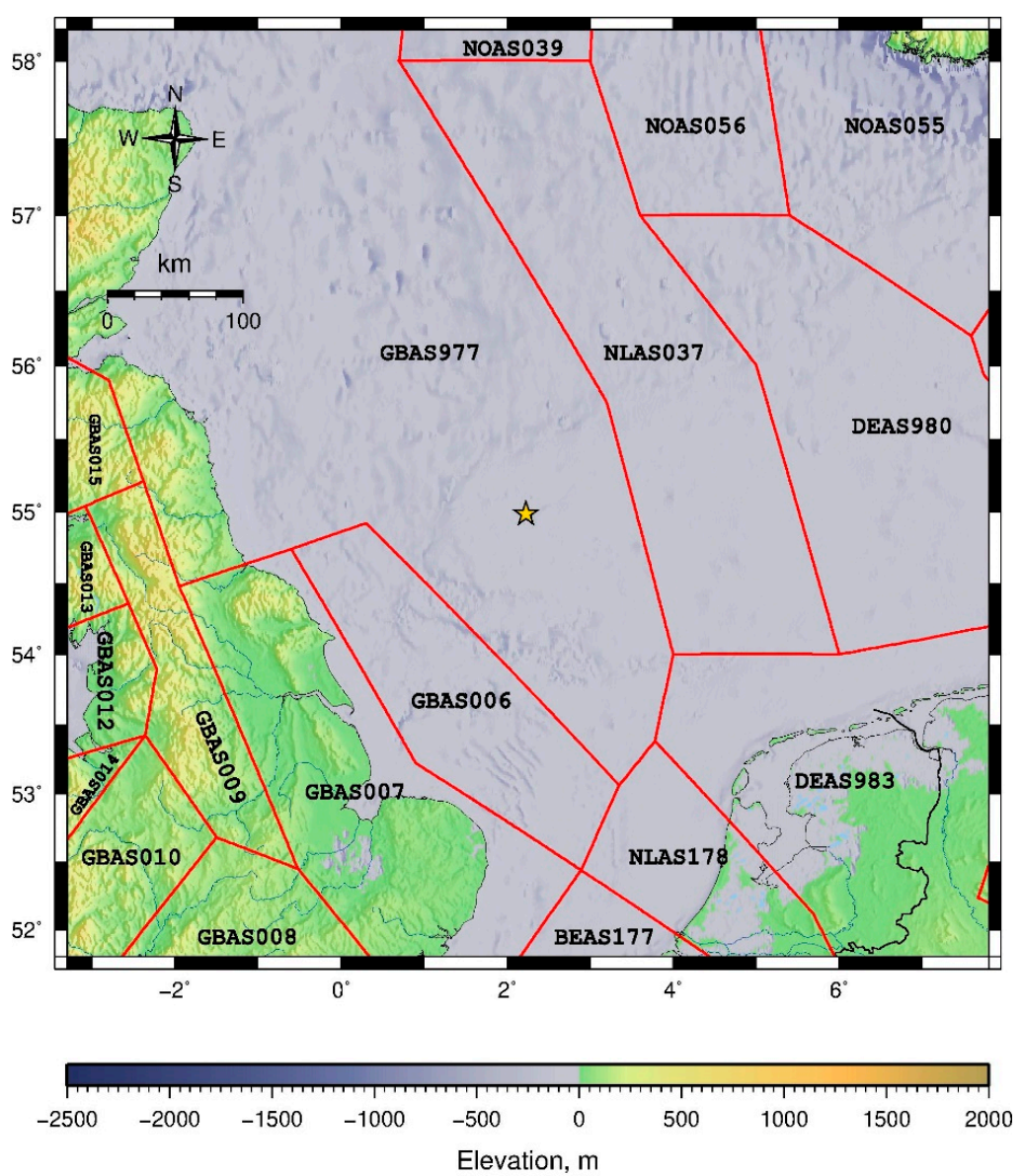

Figure 2. Location of areal source zones for SSM2 based on the SHARE project [16]. The yellow star indicates the center of the wind farm zone.

\subsection{Smooth Gridded Seismicity Source Models}

Four seismic source models were developed based on an earthquake catalogue compiled from the International Seismological Centre on-line bulletin [30] and the British Geological Survey [31] for earthquakes occurring within a $500 \mathrm{~km}$ radius of the site. The ISC catalogue is based on instrument recordings and for this area contains data from 1927 to 2020. The BGS catalogue contains both instrumental and historical earthquakes from 1382 to 2020. The two catalogues were merged and duplicates were removed, with precedence given to the BGS catalogue. Figure 3 shows the merged earthquake catalogue. The largest earthquake in the database is the 1931 Dogger Bank earthquake (blue pentagon in Figure 3). According to the BGS catalogue, it occurred $111 \mathrm{~km}$ to the southwest of the site and had a local magnitude $M_{L}=6.1$, whereas the ISC catalogue places the earthquake at $126 \mathrm{~km}$ from 
the site with a surface wave magnitude $M_{S}=5.6$. The more conservative interpretation from the BGS was used in the final catalogue.

Table 3. Source characteristics for SSM2.

\begin{tabular}{|c|c|c|c|c|c|c|c|c|c|c|c|}
\hline \multirow{2}{*}{ Zone } & \multirow{2}{*}{$N\left(M_{\min }=4\right)$} & \multirow{2}{*}{ b-Value } & \multicolumn{3}{|c|}{ Fault Mechanism (\%) } & \multirow{2}{*}{$\begin{array}{l}D_{\min } \\
(\mathrm{Km})\end{array}$} & \multirow{2}{*}{$\begin{array}{l}D_{\max } \\
(\mathbf{K m})\end{array}$} & \multirow{2}{*}{$\begin{array}{c}M_{\max , 1} \\
\text { (Weight) }\end{array}$} & \multirow{2}{*}{$\begin{array}{c}M_{\max , 2} \\
\text { (Weight) }\end{array}$} & \multirow{2}{*}{$\begin{array}{c}M_{\max , 3} \\
\text { (Weight) }\end{array}$} & \multirow{2}{*}{$\begin{array}{c}M_{\max , 4} \\
\text { (Weight) }\end{array}$} \\
\hline & & & SS & $\mathbf{N}$ & $\mathbf{R}$ & & & & & & \\
\hline BEAS177 & 0.0126 & 1.000 & 35 & 50 & 15 & 7 & 13 & $6.5(0.5)$ & $6.8(0.2)$ & $7.1(0.2)$ & $7.4(0.1)$ \\
\hline DEAS980 & 0.0051 & 1.000 & 90 & 10 & 0 & 0 & 20 & $6.5(0.5)$ & $6.7(0.2)$ & $6.9(0.2)$ & $7.1(0.1)$ \\
\hline DEAS983 & 0.0653 & 0.927 & 33 & 33 & 34 & 3 & 25 & $6.5(0.5)$ & $6.7(0.2)$ & $6.9(0.2)$ & $7.1(0.1)$ \\
\hline GBAS006 & 0.0631 & 1.000 & 33 & 33 & 34 & 0 & 20 & $6.5(0.5)$ & $6.7(0.2)$ & $6.9(0.2)$ & $7.1(0.1)$ \\
\hline GBAS007 & 0.0026 & 1.000 & 33 & 33 & 34 & 0 & 20 & $6.5(0.5)$ & $6.7(0.2)$ & $6.9(0.2)$ & $7.1(0.1)$ \\
\hline GBAS008 & 0.0119 & 1.000 & 33 & 33 & 34 & 0 & 20 & $6.5(0.5)$ & $6.7(0.2)$ & $6.9(0.2)$ & $7.1(0.1)$ \\
\hline GBAS009 & 0.0316 & 1.000 & 33 & 33 & 34 & 0 & 20 & $6.5(0.5)$ & $6.7(0.2)$ & $6.9(0.2)$ & $7.1(0.1)$ \\
\hline GBAS010 & 0.0631 & 1.000 & 33 & 33 & 34 & 0 & 20 & $6.5(0.5)$ & $6.7(0.2)$ & $6.9(0.2)$ & $7.1(0.1)$ \\
\hline GBAS012 & 0.0158 & 1.000 & 33 & 33 & 34 & 0 & 20 & $6.5(0.5)$ & $6.7(0.2)$ & $6.9(0.2)$ & $7.1(0.1)$ \\
\hline GBAS013 & 0.0038 & 0.970 & 33 & 33 & 34 & 0 & 20 & $6.5(0.5)$ & $6.7(0.2)$ & $6.9(0.2)$ & $7.1(0.1)$ \\
\hline GBAS014 & 0.0100 & 1.000 & 33 & 33 & 34 & 0 & 20 & $6.5(0.5)$ & $6.7(0.2)$ & $6.9(0.2)$ & $7.1(0.1)$ \\
\hline GBAS015 & 0.0007 & 1.000 & 33 & 33 & 34 & 0 & 20 & $6.5(0.5)$ & $6.7(0.2)$ & $6.9(0.2)$ & $7.1(0.1)$ \\
\hline GBAS977 & 0.0148 & 1.000 & 33 & 33 & 34 & 0 & 20 & $6.5(0.5)$ & $6.7(0.2)$ & $6.9(0.2)$ & $7.1(0.1)$ \\
\hline NLAS037 & 0.0631 & 1.000 & 90 & 10 & 0 & 0 & 20 & $6.5(0.5)$ & $6.7(0.2)$ & $6.9(0.2)$ & $7.1(0.1)$ \\
\hline NLAS178 & 0.0010 & 1.000 & 90 & 10 & 0 & 7 & 13 & $6.5(0.5)$ & $6.8(0.2)$ & $7.1(0.2)$ & $7.4(0.1)$ \\
\hline NOAS039 & 0.0548 & 1.002 & 33 & 33 & 34 & 0 & 34 & $6.5(0.5)$ & $6.7(0.2)$ & $6.9(0.2)$ & $7.1(0.1)$ \\
\hline NOAS055 & 0.1259 & 1.000 & 50 & 40 & 10 & 0 & 40 & $6.5(0.5)$ & $6.7(0.2)$ & $6.9(0.2)$ & $7.1(0.1)$ \\
\hline NOAS056 & 0.0178 & 1.000 & 50 & 40 & 10 & 0 & 34 & $6.5(0.5)$ & $6.7(0.2)$ & $6.9(0.2)$ & $7.1(0.1)$ \\
\hline
\end{tabular}
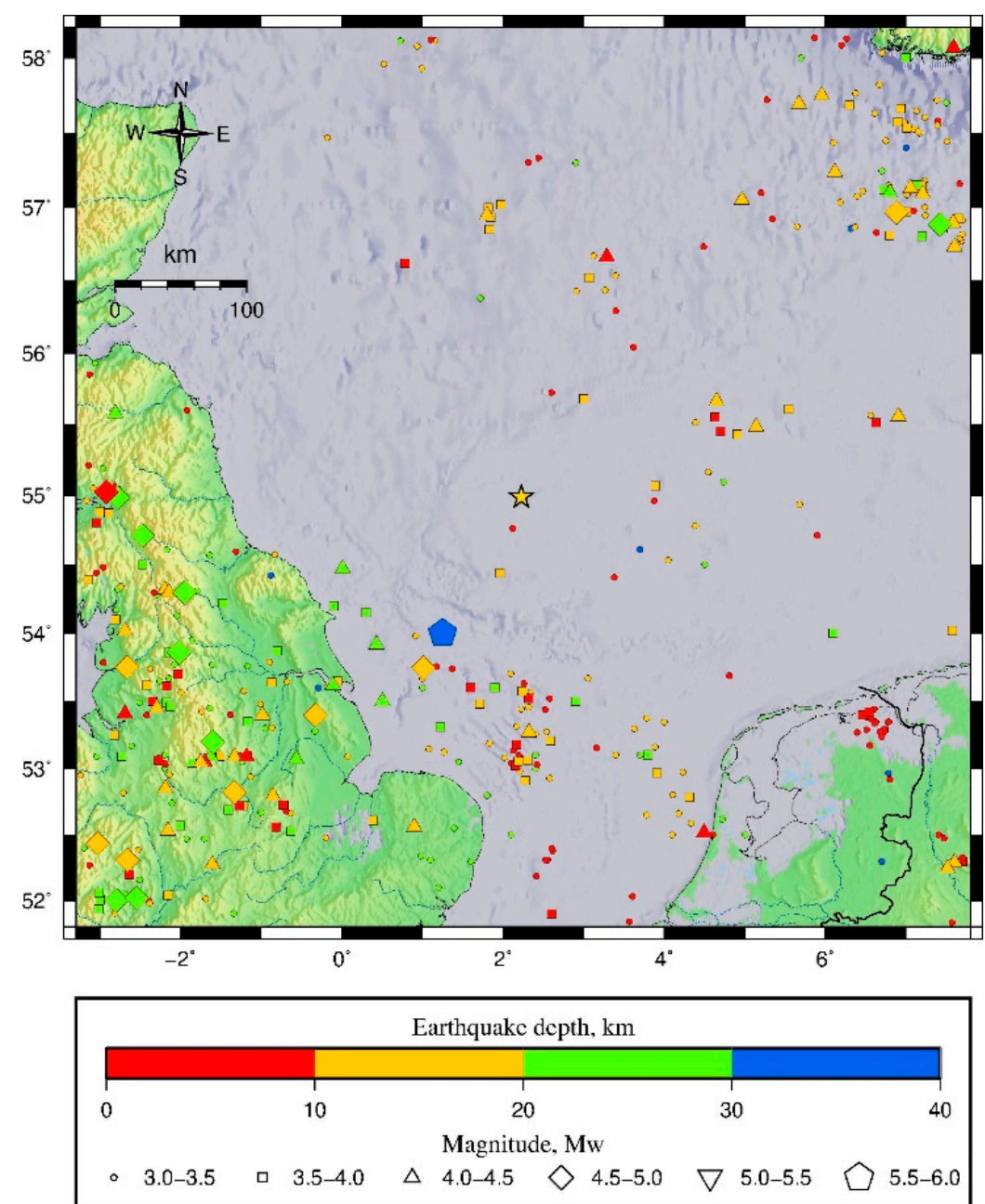

Figure 3. Merged earthquake catalogue with magnitude conversion to moment magnitude according to NRC [35]. The yellow star indicates the center of the wind farm zone. 
The earthquake magnitudes were all converted to moment magnitude $\left(M_{w}\right)$ using the midcontinent region magnitude conversion equations given in NRC [35] and those proposed by Grünthal et al. [17], with equal weight given to both methods in the logic tree framework. The NRC [35] conversion equations were developed for the Central and Eastern United States, which is a similar tectonic region to the North Sea, and the Grünthal et al. [17] equations were developed for central, northern and north-western Europe. Several other studies [36-38] also used the method proposed by Grünthal et al. [17] to convert magnitudes for sites in the UK.

PSHA assumes that all earthquake events are independent; therefore, dependent events such as foreshocks and aftershocks must be removed. The declustering models of Grünthal [39] and Reasenburg [40] were used. The Grünthal [39] method uses a magnitudedependent space and time window to define foreshocks and aftershocks. It is based on regression analyses of earthquakes from central Europe. The Reasenburg [40] model uses a time window based on Omori's law, which models the expected rate of aftershocks, and a time-dependent Poisson process. It allows for higher order aftershocks (i.e., aftershocks of aftershocks). The space window is calculated based on the estimated source dimensions of the most recent previous event in the cluster and the source dimensions of the largest event in the cluster.

The method of Stepp [41] was used to estimate completeness of the earthquake catalogue. A catalogue is complete when all earthquakes with $M>M_{\min }$ that occurred in a given area and time period are included in the catalogue. Evaluating catalogue completeness is important to prevent under-prediction of the activity rate, which can lead to unconservative results. Normally, most catalogues are incomplete for smaller magnitude earthquakes because they are harder to detect without a strong ground motion station nearby.

The method of Stepp [41] evaluates earthquake catalogues for completeness for individual magnitude bins. This allows information for larger earthquakes from historical records to be used with information from instrument records that have a much shorter time period. The Stepp [41] method assumes the earthquake sequence can be modelled as a Poisson distribution, and uses the statistical property that the variance of the estimate of a sample mean is inversely proportional to the number of observations in the sample. Therefore, the rate of occurrence of earthquakes should be approximately constant and the catalogue is incomplete when it starts to decrease. However, the mean rate of occurrence and the standard deviation will only be stable and constant in the subinterval that is not only complete, but also long enough to give a good estimate (i.e., the sample size is statistically large enough). As a result, the data might fluctuate for the first few years due to the small sample size.

Table 4 lists the completeness years for different minimum magnitudes as well as the completeness years calculated by other studies for nearby regions. The completeness years in this study are similar to those of [38] for the UK sector of the North Sea and the completeness years used by the SHARE project [16] for northern Europe. The others have significantly earlier completeness years (longer time periods) because they include large portions of onshore UK, which have better records of earthquake occurrence than offshore areas.

After the earthquake catalogues were corrected for earthquake magnitude, dependent events and completeness, the activity rate, b-value and uncertainty bounds were calculated using the maximum likelihood method [42]. The activity rates and b-values were calculated for four alternative source models (Table 5 and Figure 4). Models SS-NRC12-GR and SS-NRC12-RE use the NRC [35] magnitude conversion equations, and SS-G09-GR and SS-G09-RE use the magnitude conversion equations proposed by Grünthal et al. [17]. SS-NRC12-GR and SS-G09-GR use the Grünthal [39] declustering method, and models SS-NRC12-RE and SS-G09-RE use the Reasenberg [40] declustering method. 
Table 4. Completeness years for this study compared with several other studies for nearby regions.

\begin{tabular}{|c|c|c|c|c|c|c|}
\hline$\geq \mathbf{M}$ & $\begin{array}{l}\text { This } \\
\text { Study }\end{array}$ & $\begin{array}{l}\text { Mosca et al. [38] } \\
\text { (North Sea) }\end{array}$ & $\begin{array}{l}\text { Musson and Sergeant } \\
\text { [23] (Dogger Bank) }\end{array}$ & $\begin{array}{l}\text { Villani et al. } \\
\text { [37] (Britain) }\end{array}$ & $\begin{array}{c}\text { SHARE [16] } \\
\text { (Northern Europe) }\end{array}$ & $\begin{array}{l}\text { SHARE [16] } \\
\text { (UK) }\end{array}$ \\
\hline 3.25 & 1975 & & 1970 & 1970 & & \\
\hline 3.50 & 1975 & 1970 & & 1950 & & \\
\hline 3.75 & 1950 & & & & 1970 & 1965 \\
\hline 4.00 & 1930 & 1890 & 1850 & 1750 & 1890 & 1900 \\
\hline 4.25 & 1900 & & & & & \\
\hline 4.50 & 1820 & & 1750 & 1700 & & 1500 \\
\hline 4.75 & 1820 & 1800 & & & 1800 & \\
\hline 5.00 & 1800 & & 1650 & 1650 & & \\
\hline 5.25 & 1700 & & & & & \\
\hline 5.50 & 1700 & 1700 & & & 1700 & \\
\hline 5.75 & 1650 & & & & & \\
\hline
\end{tabular}

Table 5. Source characteristics for seismic source models based on the earthquake catalogue.

\begin{tabular}{ccc}
\hline Model & $\boldsymbol{N}\left(\boldsymbol{M}_{\min }=\mathbf{4}\right)$ & b-Value \\
\hline SS-G09-GR & 0.3574 & 0.930 \\
SS-G09-RE & 0.4042 & 0.988 \\
SS-NRC12-GR & 0.3770 & 1.124 \\
SS-NRC12-RE & 0.4358 & 1.140 \\
\hline
\end{tabular}

(a)

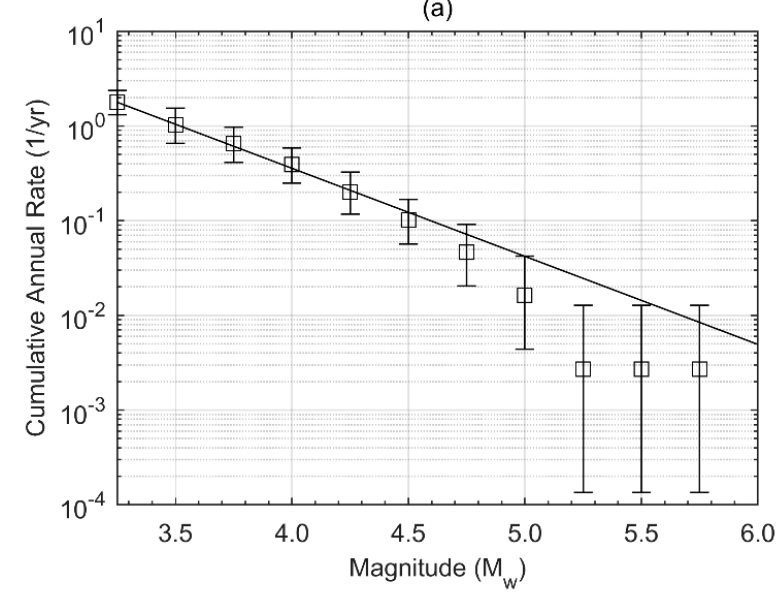

(c)

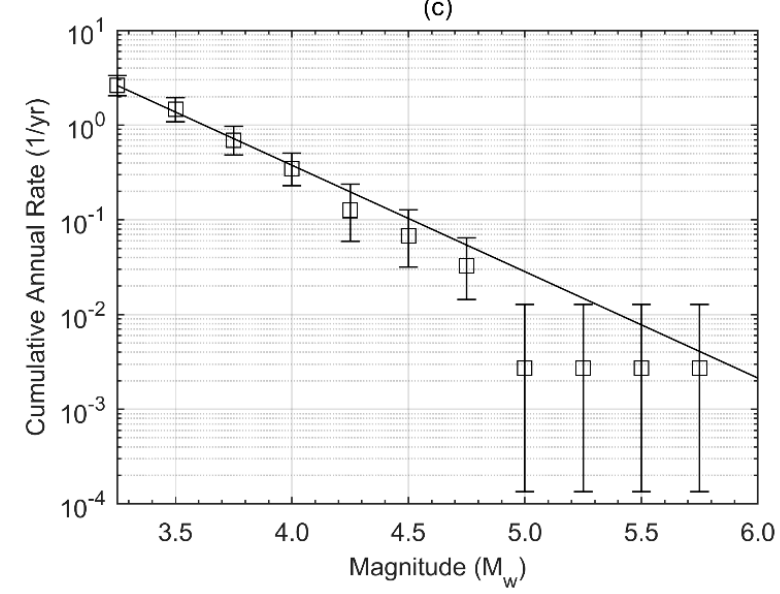

(b)

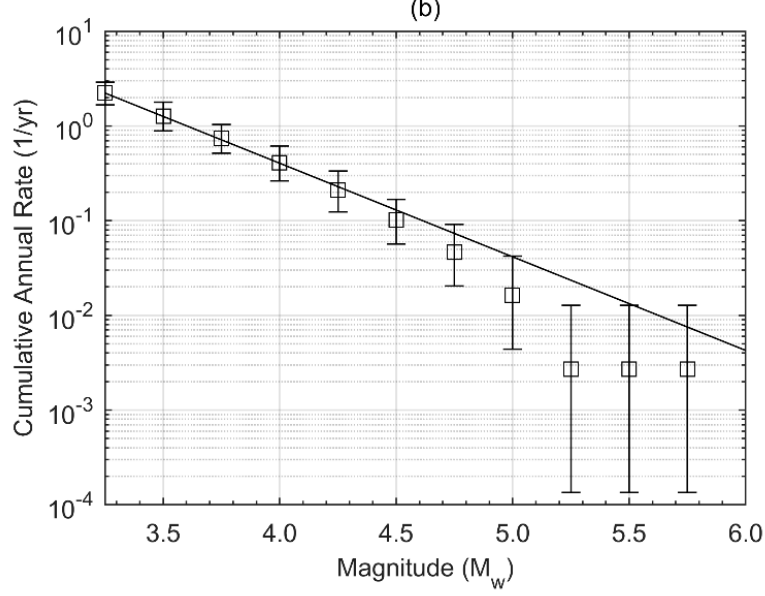

(d)

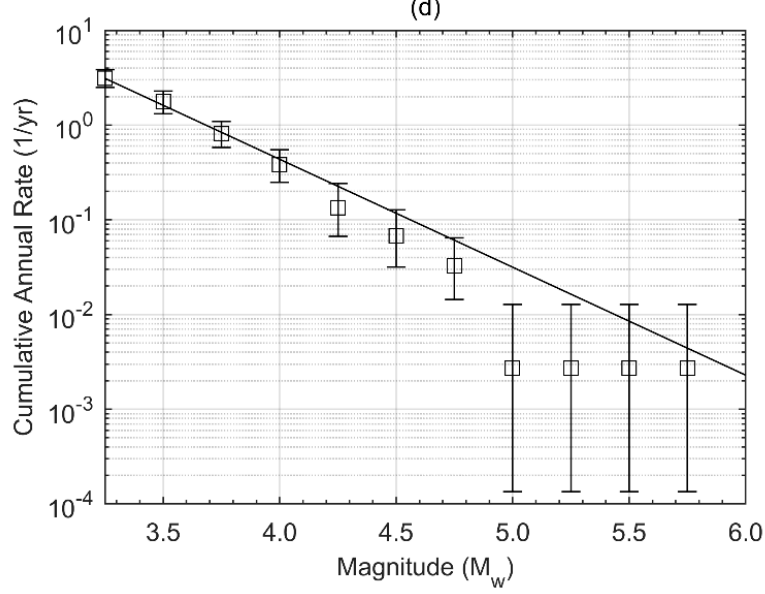

Figure 4. Magnitude recurrence relations versus cumulative annual rates for (a) SS-G09-GR, (b) SSG09-RE, (c) SS-NRC12-GR, and (d) SS-NRC12-RE. 
For each of the four source models based on earthquake catalogues, one areal source zone of $700 \times 700 \mathrm{~km}$ centered on the site was modelled using smoothed gridded seismicity. Smoothed gridded seismicity is a grid of very small areal sources with different activity rates but the same magnitude probability density function and b-value. The different activity rates represent the spatial variability of earthquake occurrence. The relative rates of each cell are based not just on the earthquakes that occurred in that cell, but a weighted average of the rates of the cell and the cells around it. A Gaussian distribution with a $30 \mathrm{~km}$ radius and $0.1 \times 0.1$ degree grid cells was used to calculate the smoothed gridded seismicity. Figure 5 shows the smoothed gridded seismicity models.
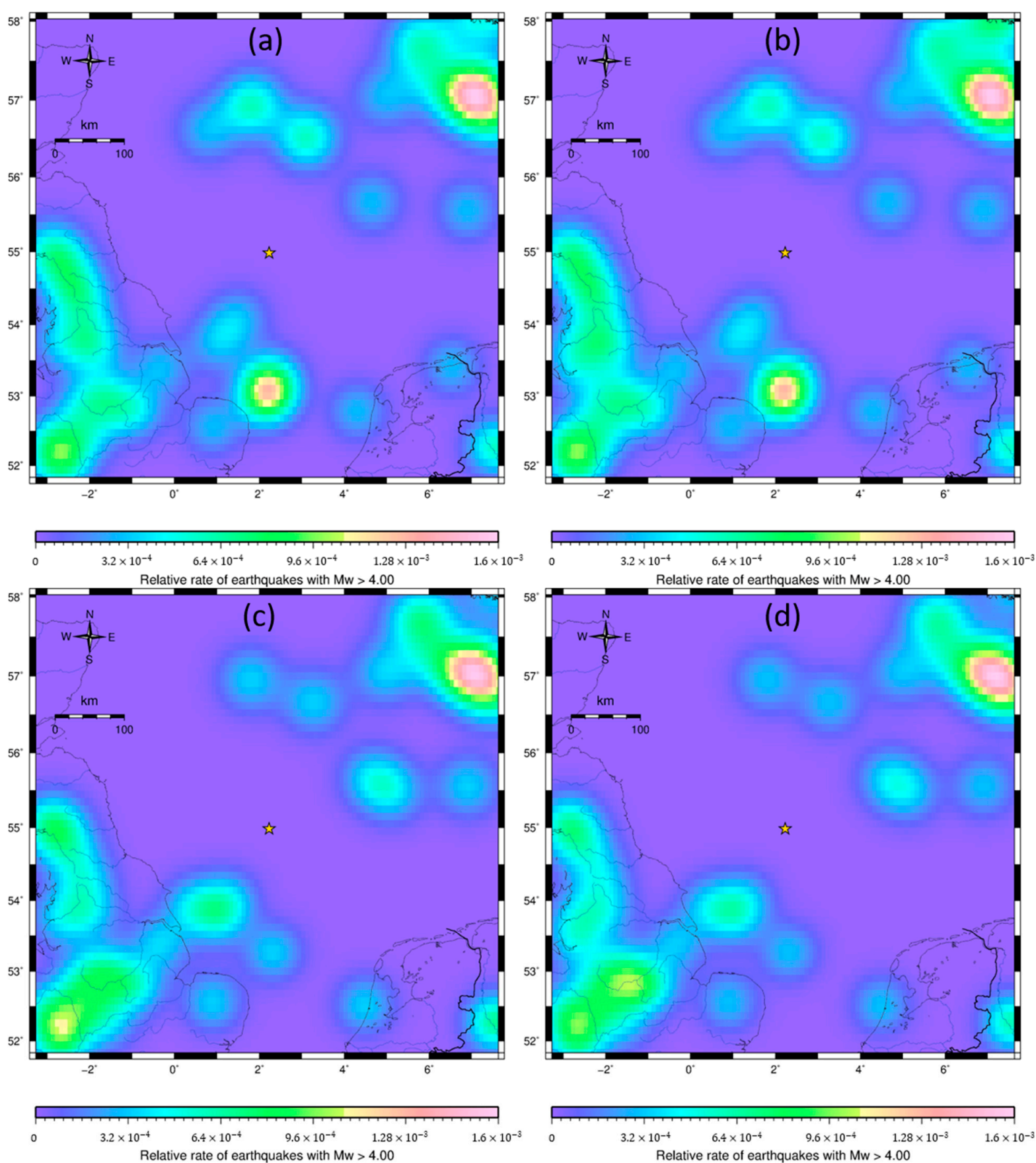

Figure 5. Smoothed gridded seismicity heat map showing the relative activity rate for (a) SS-G09-GR, (b) SS-G09-RE, (c) SS-NRC12-GR, and (d) SS-NRC12-RE. Yellow star indicates the center of the wind farm zone. 
Maximum magnitudes of 6.5, 6.7, 6.9 and 7.0 were used with weights of $0.5,0.2,0.2$ and 0.1 in the logic tree framework, which was similar to several previous studies [36-38]. The largest earthquake in the database is the 1931 Dogger Bank earthquake that had a $M_{w}=5.8\left(M_{L}=6.1\right)$, which was less than these values.

\section{Ground Motion Characterization}

There are no ground motion models developed specifically for the North Sea. When there are no site or region-specific ground motion models available, it is common practice to use models developed for similar tectonic regions and evaluate their fit with local data.

Brooks et al. [43] evaluated the fit of 16 ground motion models to recorded earthquakes from the northern North Sea region. They found that the model of Akkar et al. [44] had the best fit to the data for PGA and most spectral periods, with the models of Akkar and Çağnan [45], Rietbrock et al. [46], Abrahamson et al. [47] and Cauzzi et al. [48] providing moderate fits for some but not all spectral periods.

Villani et al. [49] evaluated GMMs for use in the UK. They first used the criteria of Bommer et al. [50] to select an initial eight GMMs from a list of 290. They did not consider GMMs developed for shield regions or eastern North America due to the different geological processes and attenuation of seismic waves from these regions compared to the UK. Villani et al. [49] then compared these eight GMMs to recorded data and macroseismic data in the UK. The recorded dataset consisted of 83 records from 12 earthquakes that occurred between 1996 and 2018 with $M_{w}$ between 3.2 and 4.5. Villani et al. [49] recommended using Bindi et al. [51], Cauzzi et al. [48], Rietbrock and Edwards [52], and one of Chiou and Youngs [53], Abrahamson et al. [47], or Boore et al. [54] for PSHA in the UK. Villani et al. [37] conducted a PSHA for a new nuclear power plant at Wylfa Newydd in North Wales. They used the GMMs of Boore et al. [54], Chiou and Youngs [53], Bindi et al. [51], Cauzzi et al. [48], and Rietbrock and Edwards [52], with weights of 0.15, 0.15, 0.20, 0.15, and 0.35 , respectively.

Tromans et al. [36] performed a PSHA for a proposed nuclear power plant at Hinkley Point, in Somerset, South-West England. They used a similar approach to Villani et al. [49] to select GMMs. They started with a large list of 400 GMMs that they reduced to 12 based on the selection criteria of Cotton et al. [55] and Bommer et al. [50]. They then compared the 12 GMMs with ground motion instrumental and intensity data retrieved as part of the project. Finally, an expert panel decided on the GMMs of Atkinson and Boore [56], Bindi et al. [51], Boore et al. [54], Cauzzi et al. [48], and Rietbrock et al. [46], with weights of 0.10, 0.30, 0.30, 0.20, and 0.10, respectively. The British Geological Survey [38] developed new seismic hazard maps for the entire UK. They used the same GMMs and weights as Tromans et al. [36].

Because the site is not located onshore in the UK or in the part of the North Sea studied by Brooks et al. [43], a combination of the GMMs found to best match both was used. This was facilitated by the fact that many of the GMMs from Brooks et al. [43], Villani et al. [37], and Tromans et al. [36] are similar. Only that of Chiou and Youngs [53], rather than both the Chiou and Youngs [53] and Abrahamson et al. [47] GMMs, were used, because these two GMMs were expected to give similar results. In addition, only Rietbrock and Edwards (2019) [52] and not Rietbrock et al. (2013) [46] was used, since the former is an update of the later. Table 6 lists the selected GMMs and the weights used in the logic tree framework.

Some of the GMMs used RotD50 spectral acceleration and some the geometric mean. However, Boore and Kishida [57] show that the difference between these two is less than 7\% for all periods. Therefore, the GMMs were not adjusted based on spectral acceleration type.

All the selected GMMs except Rietbrock and Edwards [52] used the time average shear wave velocity over the top $30 \mathrm{~m}\left(V s_{30}\right)$ to define the site conditions. This study used $V s_{30}=760 \mathrm{~m} / \mathrm{s}$ to represent soft rock conditions, which is in agreement with the reference rock condition of ISO 19901-2 $\left(V s_{30}=750 \mathrm{~m} / \mathrm{s}\right)$ [8] and EN 1998-1:2004 (Eurocode 8$)\left(V_{s_{30}}=800 \mathrm{~m} / \mathrm{s}\right)$ [58]. Rietbrock and Edwards [52] defined spectral accelerations 
for $V s_{30}=2600 \mathrm{~m} / \mathrm{s}$. To convert to $V s_{30}=760 \mathrm{~m} / \mathrm{s}$, the relations of Stewart et al. [59] were used.

Table 6. Selected GMMs and their weights in the logic tree.

\begin{tabular}{cc}
\hline GMM & Weight \\
\hline Atkinson and Boore (2011) [56] & 0.10 \\
Bindi et al. (2014) [51] & 0.15 \\
Boore et al. (2014) [54] & 0.15 \\
Cauzzi et al. (2015) [48] & 0.15 \\
Chiou \& Youngs (2014) [53] & 0.15 \\
Rietbrock \& Edwards (2019) [52] & 0.15 \\
Akkar et al. (2014) [44] & 0.10 \\
Akkar and Çağnan (2010) [45] & 0.05 \\
\hline
\end{tabular}

\section{Results and Discussion}

This study performed a PSHA for the center and all four corners of the Sofia Offshore Wind Farm. The maximum difference in the mean peak ground acceleration (PGA) between the corners and the center is only $8 \%$ for return periods from 100 to 10,000 years, indicating a small change in seismic hazard across the site. This is an important conclusion that could be useful for other infrastructure projects in the North Sea that span large areas. In the following section, only the results from the center location are presented.

Figure 6a shows the mean hazard for PGA on rock and the unweighted hazard curves for the three different source models. SSM2 based on SHARE [16] predicts the largest hazard, followed by the smooth gridded seismicity source models based on the earthquake catalogue and lastly SSM1, based on Bungum et al. [6] and Musson and Sergeant [23]. The results are similar for other spectral periods.

Figure $6 \mathrm{~b}-\mathrm{d}$ show the contribution of each source zone to the hazard for each seismic source model. Figure $6 \mathrm{c}$ shows that the smoothed seismicity models based on the magnitude conversion equations of Grünthal et al. [17] predict higher hazard than the models based on the NRC [35] magnitude conversion equations. This is because SS-G09-GR and SS-G09-RE predict higher rates of occurrence of large magnitude earthquakes, which increases the hazard (cf. Figure 4). Figure $6 \mathrm{~b}$ shows that the source most contributing to the hazard in SSM1 is EC10 at short return periods and NOR2 at long return periods. This is because EC10 has one of the highest activity rates of all the zones and is relatively close to the site. At longer return periods, NOR2 starts to dominate because it is the closest zone and has larger maximum magnitudes than EC10. Figure 6d shows that sources GBAS006, NLAS037, and GBAS977 have the largest contribution to the hazard for SSM2, mainly due to their close proximity. GBAS006 also has one of the higher activity rates. GBAS977, the source that the site is located in, has a small activity rate and only starts to influence the hazard at longer return periods. These results are similar to SSM1.

The main conclusion from these figures is that the 1931 Dogger Bank earthquake is one of the main factors influencing the hazard in this region, as shown by the effect of seismic source zones EC10 and GBAS006 (where the Dogger Bank earthquake occurred). This has important implications for future seismic hazard assessments in the North Sea or the UK.

Figure 7 shows the hazard deaggregation for $P G A$ and a spectral period of $T=1.0 \mathrm{~s}$ for a return period of 475 years, and Figure 8 shows the mean magnitude and mean distance contributing to the hazard for return periods of 100,475, 1000, 2475, and 10,000 years. These figures show that as the spectral periods increase, the mean magnitude and distance increase, and as the return period increases, the mean magnitude increases and the mean distance decreases. For a return period of 100 years, the controlling scenario at short spectral periods is $M_{w}=5.0$ and $R=170 \mathrm{~km}$, and at long spectral periods it is $M_{w}=5.5$ and $R=210$ $\mathrm{km}$. For a return period of 10,000 years, the controlling scenario at short spectral periods is $M_{w}=5.5$ and $R=110 \mathrm{~km}$, and at long spectral periods it is $M_{w}=6.3$ and $R=170 \mathrm{~km}$. These results are significant because they show that the dominant earthquake scenarios are from relatively large distances and low magnitudes, which is unique to the North Sea. 
(a)

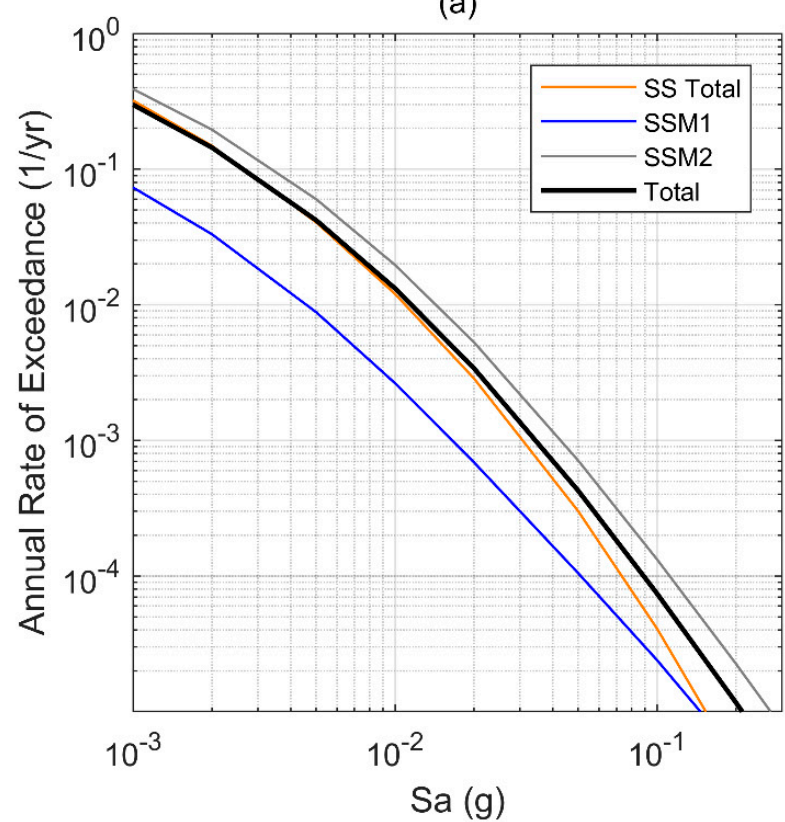

(c)

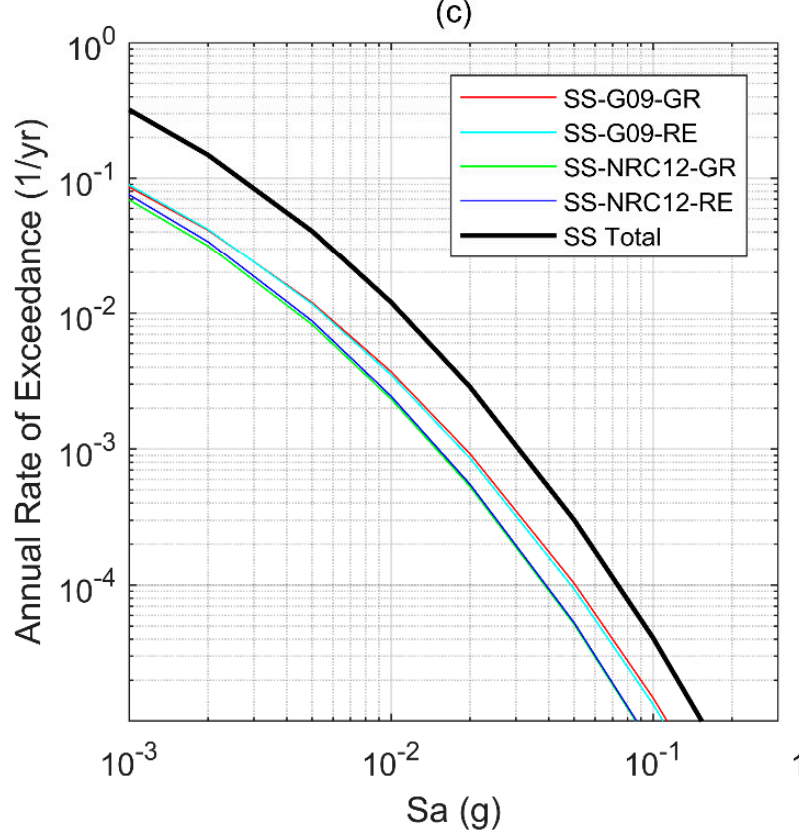

(b)

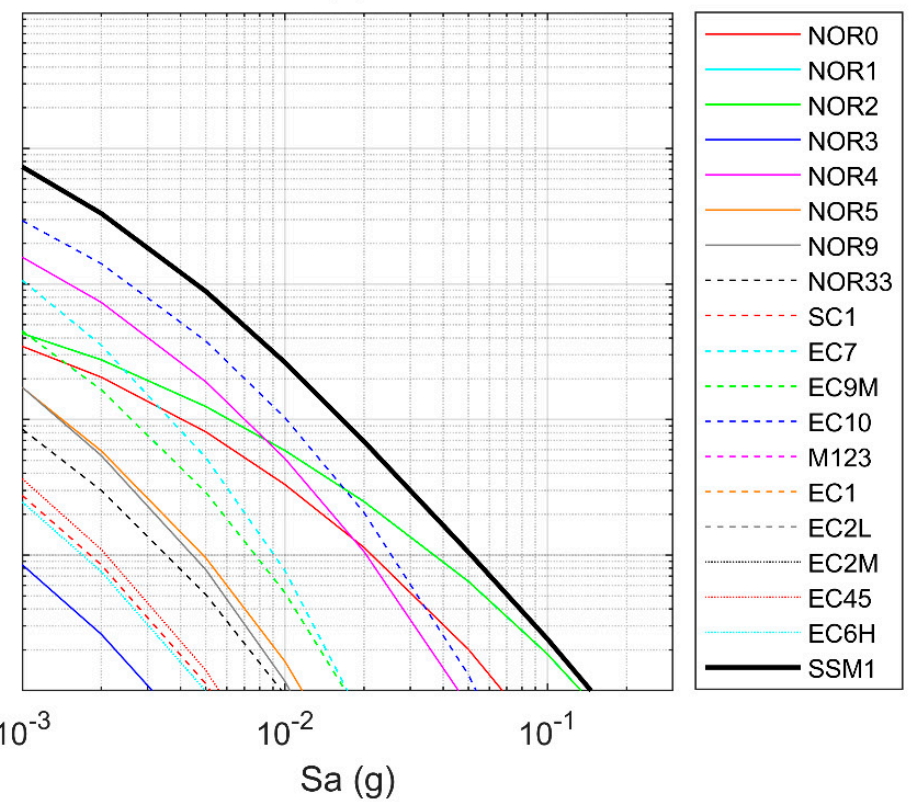

(d)

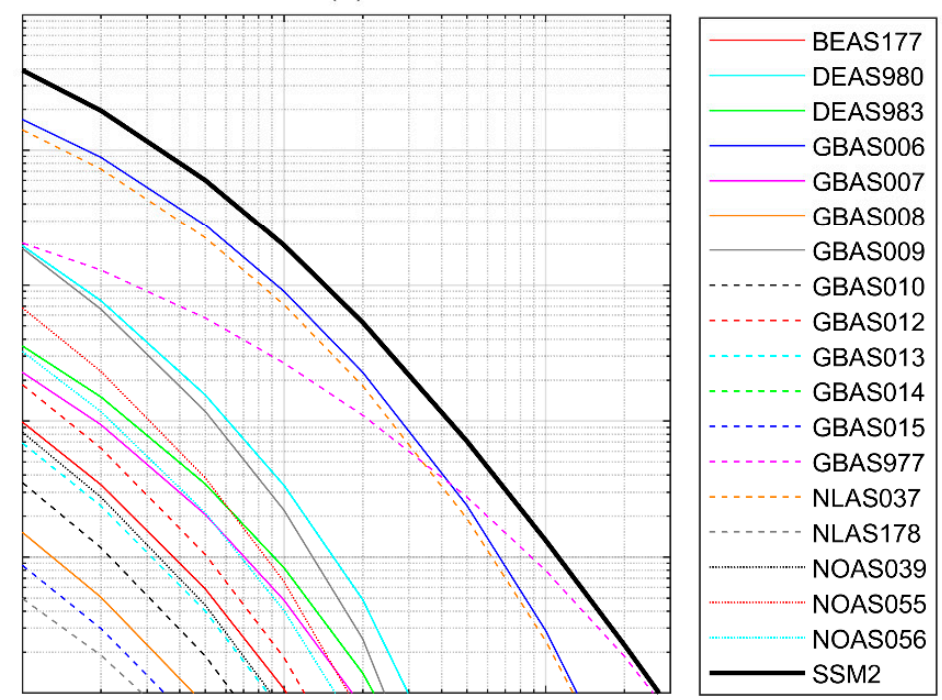

$\mathrm{Sa}(\mathrm{g})$

Figure 6. Results for PGA on rock showing (a) the unweighted hazard curves for the three source models versus the total mean hazard curve, (b) the contribution of the different source zones to SSM1, (c) the contribution of the different smoothed seismicity models to the total hazard for the smoothed seismicity models (SS Total), and (d) the contribution of the different source zones to SSM2.

Figure 9 presents the mean uniform hazard spectra (UHS) for five different common return periods. Table 7 presents a comparison of $P G A$ values on rock for several return periods from different studies. The results of this study are generally lower than previous studies. This is most likely because the previous studies are all more than 17 years old (the update of ISO 19901-2 in 2017 did not include a reevaluation of the seismic hazard for the North Sea, so the seismic hazard values are the same as in 2004). Since then, there have been significant improvements in PSHA methodology, especially ground motion models, and an increase in available data for the North Sea. In addition, the previous studies were 
all regional analyses focused more on the UK with differences of almost a factor of two. The UHS and the results of the deaggregation could be used to help in the selection of appropriate acceleration time series for future seismic hazard studies in the North Sea.

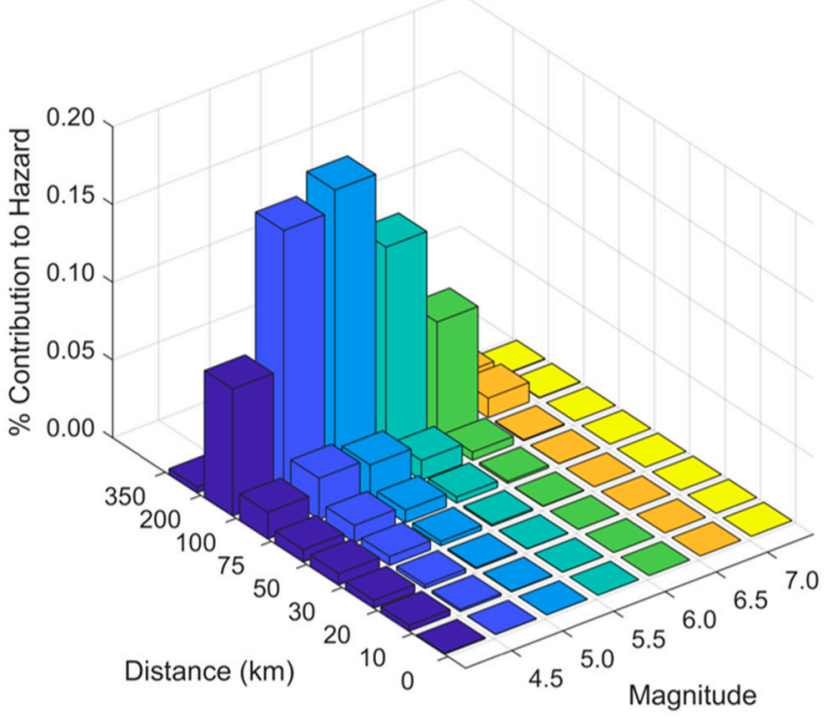

(a)

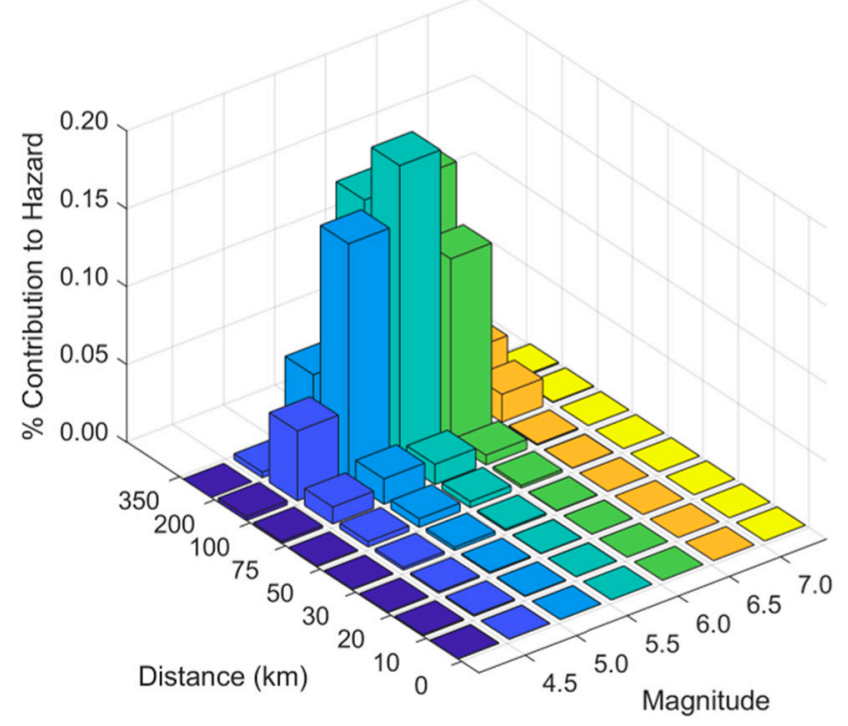

(b)

Figure 7. Hazard deaggregation for (a) $P G A$ and (b) $S a(T=1)$ on rock for 475-year return period.

(a)

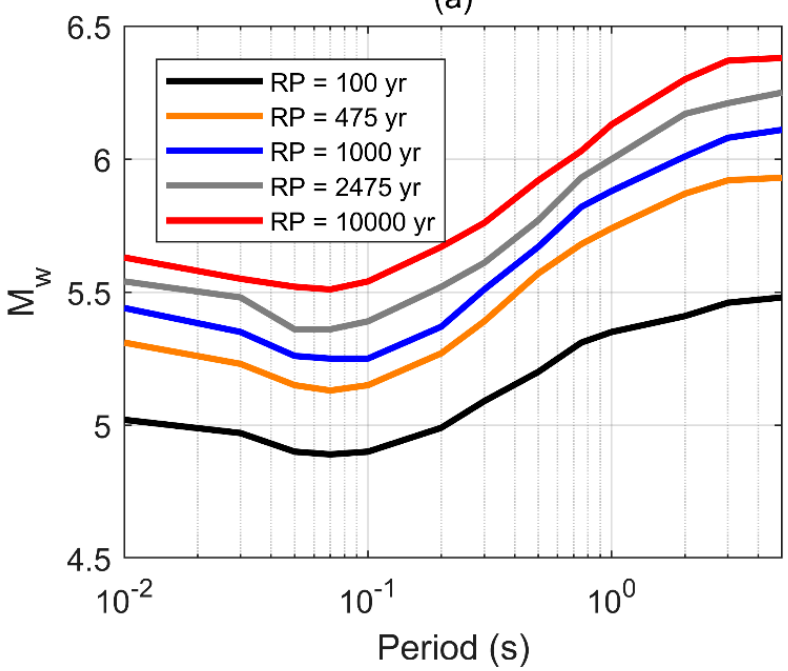

(b)

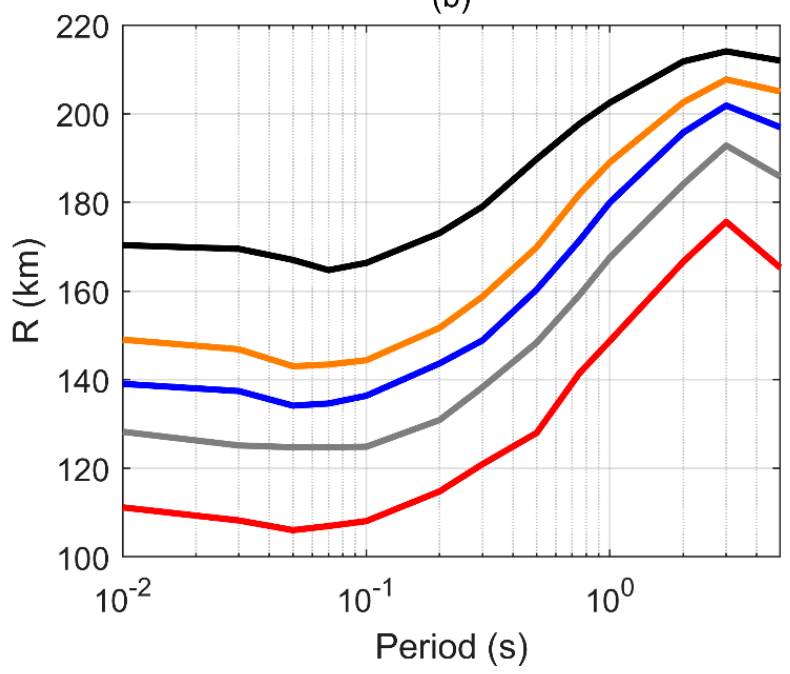

Figure 8. Mean (a) magnitude and (b) source to site distance contributing to the hazard at different spectral and return periods (RP).

The results presented in this paper are for a rock site and do not include the effect of overlying sediment. Site amplification is a very local effect and will, therefore, change across the area of the wind farm. The significance of the site effects depends on the soil stiffness and type, as well as the intensity, duration, and frequency content of the ground shaking [60].

ISO 19901-2 [8] requires offshore structures to satisfy the design criteria for Extreme Level Earthquakes (ELE) and Abnormal Level Earthquakes (ALE). The return periods for these two design levels are calculated based on the hazard curves and depend on the exposure level of the structure. For structures such as offshore wind turbines that do not have personnel on them, exposure level L1 corresponds to high-consequence structures, L2 for medium-consequence, and L3 for low-consequence structures. For exposure levels 
L1, L2 and L3, we calculated ELE and ALE return periods of 950 and 3000, 450 and 1200, and 200 and 450 years, respectively. Klose et al. [61] recommend design return periods of 95 years for Serviceability Limit State (SLS) and 475 years for Ultimate Limit State (ULS). These return periods roughly correspond to the return periods for exposure level L3 based on the ISO 19901-2 procedures.

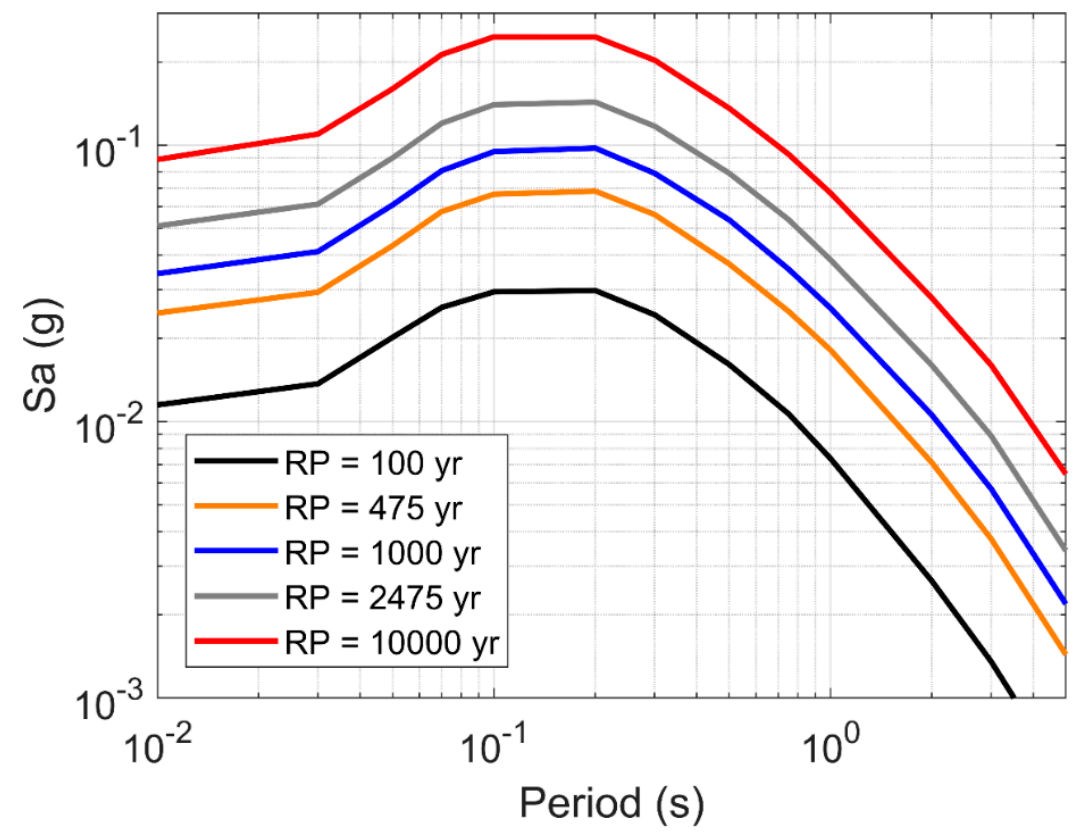

Figure 9. Mean uniform hazard spectra for different return periods (RP).

Table 7. Comparison of $P G A(\mathrm{~g})$ values on rock for different return periods.

\begin{tabular}{cccccc}
\hline \multirow{2}{*}{ Reference } & \multicolumn{5}{c}{ Return Period (Years) } \\
\cline { 2 - 5 } & $\mathbf{1 0 0}$ & $\mathbf{4 7 5}$ & $\mathbf{1 0 0 0}$ & $\mathbf{2 4 7 5}$ & $\mathbf{1 0 , 0 0 0}$ \\
\hline This study & 0.011 & 0.025 & 0.034 & 0.050 & 0.089 \\
\hline PML (1986) [2] & 0.032 & & 0.180 \\
\hline BGS \& Arup (1997) [3] & 0.020 & 0.040 & 0.090 \\
\hline EQE International (2002) [4] & 0.014 & 0.030 & 0.120 \\
\hline Mallard et al. (2003) [7] & 0.014 & 0.040 & 0.125 \\
\hline ISO 19901-2:2017 [8] & & & \\
\hline
\end{tabular}

\section{Conclusions}

This paper presented a probabilistic seismic hazard analysis (PSHA) for the corners and center of the Sofia Offshore Wind Farm for a reference rock site condition $\left(V s_{30}=760 \mathrm{~m} / \mathrm{s}\right)$. This is the first PSHA available in the literature for the UK sector of the North Sea for almost 20 years. This study highlights the effect of epistemic uncertainty on seismic source models and explores which sources and which magnitude and distance scenarios control the hazard for the North Sea, which had not been thoroughly studied previously. The main findings from the study are:

- There is a negligible difference in results between the center and four corners of the wind farm. This finding is important for other infrastructure projects in the North Sea that cover large areas, such as wind farms. Instead of performing PSHA for each wind turbine location, the results from this study show that results from the center of the wind farm are adequate for the entire wind farm area.

- The main source controlling the hazard is the source that includes the 1931 Dogger Bank earthquake. Additional studies to characterize this earthquake could, therefore, 
be beneficial to reduce uncertainty for seismic hazard analyses in the UK sector of the North Sea.

- The earthquake scenarios controlling the hazard are $M_{w}=5.0-6.3$ and $R=110-210 \mathrm{~km}$. Compared to other regions, these magnitudes are relatively low and the distances large. This result will help guide the selection of appropriate acceleration time series for other seismic hazard studies in the North Sea.

- For exposure levels L1, L2, and L3, the ISO 19901-2 ELE and ALE return periods are 950 and 3000, 450 and 1200, and 200 and 450 years, respectively.

- The peak ground acceleration (PGA) on rock for return periods of 475 years and 2475 years are $0.025 \mathrm{~g}$ and $0.050 \mathrm{~g}$, respectively, which indicates low seismic hazard. These values are lower than previous studies, most likely due to the improved ground motion models used in the PSHA calculations.

The results of this study provide the scientific and engineering community with information that was not previously known and could significantly improve seismic hazard assessments in the North Sea.

Author Contributions: Methodology, B.C.; formal analysis, B.C.; writing-original draft preparation, B.C.; writing-review and editing, A.M.K. and A.B.; supervision, A.M.K.; funding acquisition, A.B. All authors have read and agreed to the published version of the manuscript.

Funding: This research was funded by RWE in connection with development of the Sofia Offshore Wind Farm.

Conflicts of Interest: The funders defined the scope of the study and approved the manuscript for publication, but had no role in the design of the study; in the collection, analyses, or interpretation of data; in the conclusions; or in the writing of the manuscript.

\section{References}

1. Kaynia, A.M. Seismic considerations in design of offshore wind turbines. Soil Dyn. Earthq. Eng. 2019, 124, 399-407. [CrossRef]

2. Principia Mechanica Ltd. North Sea Seismicity; UK Dept. of Energy Offshore Technology Report No. OTH 86 219; HMSO: London, UK, 1986; p. 73.

3. BGS \& Ove Arup and Partners. UK Continental Shelf Seismic Hazard; Health and Safety Executive Offshore Technology Report OTH 93 416; HMSO: London, UK, 1997; p. 103.

4. EQE International Ltd. Seismic Hazard-UK Continental Shelf; Health and Safety Executive Offshore Technology Report 2002/005; Health and Safety Executive (HSE): London, UK, 2002; p. 70.

5. Bungum, H.; Lindholm, C.D.; Dahle, A.; Hicks, E.; Høgden, S.; Nadim, F.; Holme, J.K.; Harbitz, C. Development of Seismic Zonation for Norway: Final Report; Norwegian Council for Building Standardization (NBR): Oslo, Norway, 1998; p. 187.

6. Bungum, H.; Lindholm, C.D.; Dahle, A.; Woo, G.; Nadim, F.; Holme, J.K.; Gudmestad, O.T.; Hagberg, T.; Karthigeyan, K. New seismic zoning maps for Norway, the North Sea, and the United Kingdom. Seismol. Res. Lett. 2000, 71, 687-697. [CrossRef]

7. Mallard, D.J.; Skipp, B.O.; Aspinall, W.P. An Appraisal of Existing Seismic Hazard Estimates for the UK Continental Shelf; Health and Safety Executive Research Report 166; Health and Safety Executive (HSE): London, UK, 2003; p. 83.

8. ISO 19901-2. Petroleum and Natural Gas Industries-Specific Requirements for Offshore Structures-Part 2: Seismic Design Procedures and Criteria; International Organization for Standardization: Geneva, Switzerland, 1997; p. 52.

9. Kramer, S. Geotechnical Earthquake Engineering; Prentice and Hall: Upper Saddle River, NJ, USA, 1996; p. 653.

10. Abrahamson, N. HAZ45.2. Available online: https://github.com/abrahamson/HAZ (accessed on 2 January 2017).

11. Hale, C.; Abrahamson, N.; Bozorgnia, Y. Probabilistic Seismic Hazard Analysis Code Verification; PEER Report No. 2018/03; Pacific Earthquake Engineering Research Center: Berkeley, CA, USA, 2018; p. 103.

12. Cornell, C.A. Engineering seismic risk analysis. Bull. Seismol. Soc. Am. 1968, 58, 1583-1606. [CrossRef]

13. McGuire, R.K. Seismic Structural Response Risk Analysis Incorporating Peak Response Regressions on Earthquake Magnitude and Distance; Massachusetts Institute of Technology Department of Civil Engineering/Research Report R74-51; Massachusetts Institute of Technology: Cambridge, MA, USA, 1974.

14. McGuire, R.K. FRISK: Computer Program for Seismic Risk Analysis Using Faults as Earthquake Sources; U.S. Geological Survey Open-File Report; U.S. Geological Survey: Menlo Park, CA, USA, 1978; pp. 78-1007.

15. Kulkarni, R.B.; Youngs, R.R.; Coppersmith, K.J. Assessment of confidence intervals for results of seismic hazard analysis. In Proceedings of the Eighth World Conference on Earthquake Engineering, San Francisco, CA, USA, 21-28 July 1984; Volume 1, pp. 263-270. 
16. Woessner, J.; Laurentiu, D.; Giardini, D.; Crowley, H.; Cotton, F.; Grünthal, G.; Valensise, G.; Arvidsson, R.; Basili, R.; Demircioglu, M.B.; et al. The 2013 European Seismic Hazard Model: Key components and results. Bull. Earthq. Eng. 2015, 13, 3553-3596. [CrossRef]

17. Grünthal, G.; Wahlström, R.; Stromeyer, D. The unified catalogue of earthquakes in central, northern, and northwestern Europe (CENEC) - updated and expanded to the last millennium. J. Seismol. 2009, 13, 517-541. [CrossRef]

18. Grünthal, G. and the GSHAP Region 3 Working Group. Seismic hazard assessment for Central, North and Northwest Europe: GSHAP Region 3. Ann. Di Geofis. 1999, 42, 999-1011.

19. Glennie, K.W.; Underhill, J.R. Development and Evolution of Structural Styles. In Petroleum Geology of the North Sea: Basic Concepts and Recent Advances; Wiley Online Library: Hoboken, NJ, USA, 1998. [CrossRef]

20. NPD. $\mathrm{CO}_{2}$ Atlas for the Norwegian Continental Shelf-Chapter 4.1: Geology of the North Sea. Norwegian Petroleum Directorate. Available online: https:/ / www.npd.no/en/facts/publications / co2-atlases/co2-atlas-for-the-norwegian-continental-shelf/4the-norwegian-north-sea/4.1-geology-of-the-north-sea/ (accessed on 1 October 2019).

21. Cotterill, C.; Long, D.; James, L.; Forsberg, C.F.; Phillips, E.; Ruiter, A.; Tjelta, T.I.; Dove, D. The evolution of the Dogger Bank, North Sea: A complex history of terrestrial, glacial and marine environmental change. Quat. Sci. Rev. 2017, 171, 136-153. [CrossRef]

22. Lee, J.R.; Rose, J.; Candy, I.A.N. Sea-level changes, river activity, soil development and glaciation around the western margins of the southern North Sea Basin during the Early and early Middle Pleistocene: Evidence from Pakefield, Suffolk, UK. J. Quat. Sci. 2006, 21, 155-179. [CrossRef]

23. Musson, R.M.W.; Sargeant, S.L. Eurocode 8 Seismic Hazard Zoning Maps for the UK; Seismology and Geomagnetism Programme Technical Report CR/07/125; British Geological Survey: Keyworth, UK, 2007; p. 70.

24. Chadwick, R.A.; Pharaoh, T.C.; Williamson, J.P.; Musson, R.M.W. Seismotectonics of the UK; British Geological Survey Technical Report; WA/96/3C; British Geological Survey: Keyworth, UK, 1996.

25. Baptie, B. Seismogenesis and state of stress in the UK. Tectonophysics 2010, 482, 150-159. [CrossRef]

26. Baptie, B. Stress Field Orientations in North Wales: Implications for Preferred Faulting Directions; British Geological Survey Commercial Report; CR/13/139; British Geological Survey: Keyworth, UK, 2014.

27. Musson, R.M.W. Evaluation of Seismic Hazard Source Models. In Seismicity Modelling in Seismic Hazard Mapping; Lapajne, J., Vidrih, R., Eds.; Slovenian Geophysical Survey: Ljubljana, Slovenia, 2000.

28. Musson, R.M.W. The seismicity of the British Isles. Ann. Geofis. 1996, 39, 463-469.

29. Muir Wood, R. Deglaciation seismotectonics: A principal influence on intraplate seismogenesis at high latitudes. Quat. Sci. Rev. 2000, 19, 1399-1411. [CrossRef]

30. ISC. International Seismological Centre Online Bulletin. Available online: http://www.isc.ac.uk/iscbulletin/search/bulletin/ (accessed on 1 October 2019).

31. British Geological Survey. BGS Earthquake Database Search. Available online: http://www.earthquakes.bgs.ac.uk/earthquakes/ dataSearch.html (accessed on 1 October 2019).

32. Gutenberg, B.; Richter, C.F. Frequency of earthquakes in California. Bull. Seism. Soc. Amer. 1944, 34, 185-188. [CrossRef]

33. Bommer, J.J.; Crowley, H. The Purpose and Definition of the Minimum Magnitude Limit in PSHA Calculations. Seismol. Res. Lett. 2017, 88, 1097-1106. [CrossRef]

34. Giardini, D.; Woessner, J.; Danciu, L. Seismic Hazard Harmonization in Europe (SHARE): Online Data Resource. 2013. Available online: https:/ / portal.share-eu.org:8080/jetspeed/portal/ (accessed on 10 October 2019). [CrossRef]

35. NRC. Technical Report: Central and Eastern United States Seismic Source Characterization for Nuclear Facilities; DOE and U.S. NRC, 3176; EPRI: Palo Alto, CA, USA, 2013.

36. Tromans, I.J.; Aldama-Bustos, G.; Douglas, J.; Lessi-Cheimariou, A.; Hunt, S.; Daví, M.; Musson, R.M.W.; Garrard, G.; Strasser, F.O.; Robertson, C. Probabilistic seismic hazard assessment for a new-build nuclear power plant site in the UK. Bull. Earthq. Eng. 2019, 17, 1-36. [CrossRef]

37. Villani, M.; Lubkowski, Z.; Free, M.; Musson, R.M.W.; Polidoro, B.; McCully, R.; Koskosidi, A.; Oakman, C.; Courtney, T.; Walsh, M. A probabilistic seismic hazard assessment for Wylfa Newydd, a new nuclear site in the United Kingdom. Bull. Earthq. Eng. 2020, 18, 4061-4089. [CrossRef]

38. Mosca, I.; Sargeant, S.; Baptie, B.; Musson, R.; Pharaoh, T. Revising the Seismic Hazard Maps for the UK. In Proceedings of the International Conference for Society for Earthquake and Civil Engineering Dynamics (SECED), Greenwich, UK, 9-10 September 2019.

39. Grünthal, G. The Up-dated Earthquake Catalogue for the German Democratic Republic and Adjacent Areas-Statistical Data Characteristics and Conclusions for Hazard Assessment. In Proceedings of the 3rd International Symposium on the Analysis of Seismicity and Seismic Risk, Liblice, Czechia, 17-22 June 1985.

40. Reasenberg, P. Second-order moment of central California seismicity, 1969-1982. J. Geophys. Res. 1985, 90, 5479-5495. [CrossRef]

41. Stepp, J.C. Analysis of completeness of the earthquake sample in the Puget Sound Area and its effect on statistical estimates of earthquake hazard. In Proceedings of the 1st International Conference on Microzonation, Seattle, WA, USA, October 1972. Available online: https:/ / www.resolutionmineeis.us/sites/default/files/references/stepp-1972.pdf (accessed on 12 August 2021).

42. Weichert, D.H. Estimation of the earthquake recurrence parameters for unequal observation periods for different magnitudes. Bull. Seismol. Soc. Am. 1980, 70, 1337-1346. [CrossRef] 
43. Brooks, C.; Douglas, J.; Shipton, Z. Improving earthquake ground-motion predictions for the North Sea. J. Seism. 2020, 24, 343-362. [CrossRef]

44. Akkar, S.; Sandikkaya, M.A.; Bommer, J.J. Empirical ground motion models for point- and extended-source crustal earthquake scenarios in Europe and the Middle East. Bull. Earthq. Eng. 2014, 12, 359-387. [CrossRef]

45. Akkar, S.; Çağnan, Z. A local ground-motion predictive model for Turkey and its comparison with other regional and global ground-motion models. Bull. Seism. Soc. Am. 2010, 100, 2978-2995. [CrossRef]

46. Rietbrock, A.; Strasser, F.; Edwards, B. A stochastic earthquake ground-motion prediction model for the United Kingdom. Bull. Seism. Soc. Am. 2013, 103, 57-77. [CrossRef]

47. Abrahamson, N.A.; Silva, W.J.; Kamai, R. Summary of the ASK14 ground motion relation for active crustal regions. Earthq. Spectra 2014, 30, 1025-1055. [CrossRef]

48. Cauzzi, C.; Faccioli, E.; Vanini, M.; Bianchini, A. Updated predictive equations for broadband (0.01-10 s) horizontal response spectra and peak ground motions, based on a global dataset of digital acceleration records. Bull. Earthq. Eng. 2015, 13, 1587-1612. [CrossRef]

49. Villani, M.; Polidoro, B.; Ader, T.; McCully, R.; Lubkowski, Z.; Courtney, T.J.; Walsh, M. A selection of GMPEs for the UK based on ground motion and macroseismic datasets. Bull. Seism. Soc. Am. 2019, 109, 1378-1400. [CrossRef]

50. Bommer, J.J.; Douglas, J.; Scherbaum, F.; Cotton, F.; Bungum, H.; Fäh, D. On the selection of ground motion prediction equations for seismic hazard analysis. Seism. Res. Lett. 2010, 81, 783-793. [CrossRef]

51. Bindi, D.; Massa, M.; Luzi, L.; Ameri, G.; Pacor, F.; Puglia, R.; Augiera, P. Pan-European ground-motion prediction equations for the average horizontal component of PGA, PGV, and 5\%-damped PSA at spectral periods up to $3.0 \mathrm{~s}$ using the RESORCE dataset Bull. Earthq. Eng. 2014, 12, 391-430. [CrossRef]

52. Rietbrock, A.; Edwards, B. Update of the UK Stochastic Ground Motion Model Using a Decade of Broadband Data. In Proceedings of the International Conference for Society for Earthquake and Civil Engineering Dynamics (SECED), Greenwich, UK, 9-10 September 2019.

53. Chiou, B.S.-J.; Youngs, R.R. Update of the Chiou and Youngs NGA model for the average horizontal component of peak ground motion and response spectra. Earthq. Spectra 2014, 30, 1117-1153. [CrossRef]

54. Boore, D.M.; Stewart, J.P.; Seyhan, E.; Atkinson, G.M. NGAWest 2 equations for predicting PGA, PGV, and 5\%-damped PSA for shallow crustal earthquakes. Earthq. Spectra 2014, 30, 1057-1085. [CrossRef]

55. Cotton, F.; Scherbaum, F.; Bommer, J.J.; Bungum, H. Criteria for selecting and adjusting ground motion models for specific target regions: Application to central Europe and rock sites. J. Seism. 2006, 10, 137-156. [CrossRef]

56. Atkinson, G.M.; Boore, D.M. Modifications to Existing Ground-Motion Prediction Equations in Light of New Data. Bull. Seismol. Soc. Am. 2011, 101, 1121-1135. [CrossRef]

57. Boore, D.M.; Kishida, T. Relations between some horizontal component ground-motion intensity measures used in practice. Bull. Seism. Soc. Am. 2017, 107, 334-343. [CrossRef]

58. Eurocode 8 EN 1998-1. Eurocode 8: Design of Structures for Earthquake Resistance-Part 1: General Rules, Seismic Actions and Rules for Buildings; The European Union Per Regulation 305/2011; Directive 98/34/EC; Directive 2004/18/EC; European Committee for Standardization: Brussels, Belgium, 2004.

59. Stewart, J.P.; Parker, G.A.; Atkinson, G.M.; Boore, D.M.; Hashash, Y.M.A.; Silva, W.J. Ergodic site amplification model for central and eastern North America. Earthq. Spectra 2020, 36, 42-68. [CrossRef]

60. Carlton, B.; Pestana, J.; Bray, J.; Tokimastu, K. A simplified model to estimate non-liquefiable NEHRP F site design spectra. Soil Dyn. Earthq. Eng. 2018, 110, 28-42. [CrossRef]

61. Klose, M.; Wang, J.; Ku, A. Seismic Design for Offshore Wind Farms-Lessons Learnt from the ACE Joint Industry Project. In Proceedings of the ASME 2021 Conference on Ocean, Offshore and Arctic Engineering, Virtual Online, 21-30 June 2021. 